УДК 811.163.41'35

371.3::811.163.41

https://doi.org/10.18485/kij.2018.65.1_2.12

ВАЛЕНТИНА М. ИЛИЪ

Филолошки факултет

Универзитет у Београду
Оригинални научни рад

Примљен: 26. 04. 2018.

Прихваћен: 26. 05. 2018.

\title{
ПИСАҢЕ НАЗИВА УЛИЦА И ТРГОВА У ПРАВОПИСИМА И НАСТАВИ СРПСКОГ ЈЕЗИКА
}

\begin{abstract}
У раду се анализирају правила о писању назива улица и тргова у Правопису српскога језика Матице српске из 1993, у актуелном Правопису Матице српске (2010), као и у Правопису М. Дешића (школско издање). Паралелно се истражују наставни програми за основну и средњу школу, као и презентовање ове правописне подобласти у уџбеницима за српски језик трију најзаступљенијих издавача у нашим школама. Представљају се и анализирају задаци са такмичења из српског језика и језичке културе који проверавају познавање писања улица и тргова. Дају се резултати анкете спроведене међу наставницима и професорима српског језика која испитује њихов однос према овој правописној теми. На крају се, кроз пет систематизованих правила, нуде решења за превазилажење присутног проблема у вези са писањем назива улица и тргова.
\end{abstract}

Кључне речи: правопис, називи улица и тргова, велико слово, наставни програм, уџбеници, анкета.

\section{1. Уводна напомена}

1.1. Област писања великог слова у нашем правопису је након објављивања Правописа српскохрватског језика Матице српске (1960) доживела измене за које не можемо рећи да су корените, али ни не тако безначајне, будући да су се конкретна решења у каснијим правописима мењала, а то је директно утицало на писменост сваког појединца. Међу основним смерницама за развој српске ортографске норме М. Пешикан ће издвојити и Дораде и поправке норме писања

*valentina.ilic@fill.bg.ac.rs

** Овај рад је настао на основу радионице под називом $O$ неким правописним проблемима $y$ настави српског језика одржане на 59. Републичком зимском семинару за наставнике и професоре српског језика и књижевности, који је трајао 8-10. фебруара 2018. године на Филолошком факултету Универзитета у Београду, у организацији Друштва за српски језик и књижевност Србије. 
великог слова, наводећи неке постојеће измене из ове области у тада важећем Правопису из $1993^{1}$, што указује да је правописна норма на овом пољу још увек била несавршена и да је „овде оправдано увођење више иновираних образаца” (Пешикан 1996: 197). Писање назива улица и тргова, пак, није било подвргнуто нарочитим изменама, али објашњења овог правила до данас корисницима правописа стварају честе недоумице, а наставницима неретко дилеме приликом обраде ове правописне области.

\section{2. Правописи српског језика: правила о писању назива улица}

2.1. Узрок проблему у вези са писањем назива улица лежи у чињеници да је ова, на први поглед веома једноставна тачка правописа, у њему помало закомпликована. Редактори актуелног Правописа Матице српске (2010) покушали су да ранија решења (из 1993), иначе доста заметнија, поједноставе, међутим, и она приљежним корисницима Правописа неретко доносе дилеме. Правопис српског језика (школско издање) М. Дешића, који је усаглашен са важећим Матичиним Правописом, ову партију подробније разјашњава, што свим читаоцима, а нарочито наставницима српског језика и ученицима, може олакшати разумевање и примену правила о писању улица (и тргова). Пођимо сада редом и погледајмо која су решења нудили и нуде наши правописни приручници.

а) Правопис српскога језика Матице српске (1993)

2.2. Иако је структурни карактер ових микротопонимијских вишечланих назива овде прилично детаљно разложен, чини се да је овај сегмент ипак остао неразјашњен, те читаоцима ствара недоумице у вези са конкретним правописним решењима. За ову прилику издвојићемо срж проблема у делу текста о писању назива улица. Поставља се питање како „схватити” реч улица која се јавља на почетку - припада ли званичном називу или је само општи, одвојиви део имена. Проблем додатно потхрањује и чињеница да се о писању назива улица и тргова пише у одељку Писање вишечланих израза кад је одредбени део на другом месту, па ни Садржај просечном кориснику не олакшава проналажење овог сегмента. Већ на самом почетку аутори истичу: „Недоумице и колебања у писању великог слова у првом обрасцу² изазивају случајеви кад се (из метричких или других стилских разлога) саставнице нађу у обратном реду (инверзији), а у другом обрасцу ${ }^{3}$ случајеви кад је нејасно представља ли именица почетак властитог

\footnotetext{
${ }^{1}$ Упоредити нормативна решења из 1960. и 1993. у вези са писањем назива административних јединица, историјских и савремених (Београдски пашалук, Јужнобачки округ); ратова, буна и битака (Балкански рат, Сељачка буна, Колубарска битка); слободно стилизованих назива држава (Турско иарство, Земља хиљаду језера); небеских тела (Кумова слама); острва (Огњена земља); као и појединачних назива - Библија, Марсељеза, Бог.

${ }^{2}$ Придевска одредба + именица (нпр. Босанска улииа) - фуснота је наша, В. И.

${ }^{3}$ Именица + падежна одредба (нпр. Булевар војводе Мишића) - фуснота је наша, В. И.
} 
имена или пак најавну општу реч иза које тек следи право име" (Правопис 1993: 72), притом додајући да та питања нису правописно решена, те да у вези с тим у овом приручнику можемо пронаћи само неке савете. У даљем тексту поменути савети не разрешавају наше дилеме, што врло јасно илуструје тачка која следи: „Кад се појединачни пуни назив који почиње речју УЛИЦА употреби у слободном тексту, нема сметње да се примени начин писања предвиђен у П (т. 17), где су наведени примери Улица босанска, Улица сочијалистичке револуичије [...] Међутим, будући да реч УЛИЦА у овим примерима није неодвојиви део имена, није језички погрешно ако се она схвати као најавна општа реч и пише малим словом, а великим словом почетак карактеристичног имена: улииа Босанска (боље: Босанска улииа), улица Бранка Радичевића [...] итд. Овом другом начину писања [улииа Босанска] дата је предност у П, а он је нарочито погодан ако се реч 'улица' скрати у 'ул." (Правопис 1993: 73-74; подвлачење је наше, В. И.).

2.3. У школском издању овог правописа правила за писање назива улица нису много једноставнија за разумевање, иако је овај приручник намењен ученицима. Постојеће бивалентно решење са јасно истакнутом условношћу о (не)припадању речи улица званичном називу, која се у највећем броју случајева „употребљава или подразумева” на почетку или на крају имена, заправо није решење у правом смислу, те је ђацима и наставницима у пракси доследно стварао тешкоће: „У појединачној употреби (нпр. у слободном тексту или у писању адресе) називи с почетном необавезном речју улица могу се двојако писати; (1) Улица Његошева, Улица босанска (бољи је склоп Његошева улииа, Босанска улииุа), Улица Ђуре Јакиића, Улица мајке Јевросиме; (2) улица (или ул.) Његошева, улица Босанска, улица Буре Јакиића, улица Мајке Јевросиме. Избор зависи од тога схвата ли се реч улица као почетак имена или као најавна терминска реч иза које следи име" (школско издање Правописа 1993: 36) ${ }^{4}$. Једино су недвосмислени случајеви када уз реч улица долази једночлани генитив - таква имена се не могу скраћивати, па се увек пишу великим почетним словом (исп. Улица липа, Улица бродараца / *Липа, *Бродаращза), што је истакнуто и у пуном, лингвистичком издању овог правописа.

б) Правопис српскога језика Матице српске (2010)

2.4. Нови Правопис (2010) доноси на први поглед знатно поједностављен (п)опис ортографских решења. Називи тргова и улица издвојени су у једној, посебној подтачки (54.б), која се састоји само из низа примера:

Теразије, Студентски трг, Трг ослобођења, Трг револуичје, Булевар ияара Лазара, Дунавски кеј, Немањина обала, Кружни пут, Футошки пут, Обилићев венач, Косовска, Фрушкогорска, Улииа Буре Јакиића, Улииа владике Данила, Улица српских владара, Улица платана, Улица бродараца ${ }^{5}$ (Правопис 2010: 63).

\footnotetext{
${ }^{4}$ За потребе овог рада користили смо шесто издање овог правописа. У списку литературе наведен је под референцом Правопис ${ }^{\mathbf{2 0 0 6}}$.

${ }_{5}^{5}$ Тако и: Трг републике, в. напомену уз т. 59 у Правопису (2010).
} 
На основу овакве егземплификације основна правила изводе се прилично с лакоћом:

(1) Када реч улица није конститутивни елемент назива, у писању се поштује правило о великом почетном слову прве речи (осим ако друга реч није властито име) (Теразије, Трг ослобођењ а, Обилићев венаи);

(2) Када је на другом месту у називу (уобичајени ред речи), улица се пише малим словом, а тада ову реч можемо и изоставити (Косовска (улица), Фрушкогорска (улица));

(3) Када је реч улииа на првом месту у називу (у инверзији), пише се великим почетним словом, а остатак назива само ако је властито име (Улица Ђуре Јакшића, Улица владике Данила; Улица платана, Улийа бродараия).

На основу ових правила, која директно произилазе само из датих примера, правописна тачка 54.б. не само да би била лако разумљива и научива већ би се сигурно фреквентније испитивала у задацима из правописа у тестовима намењеним нашим ученицима. Ситуацију, међутим, компликују две напомене које стоје уз наведене примере, које ово правило и даље чине ненаучивим:

\footnotetext{
„Напомена 1: У склопу најраширенијег модела именовања улица, с меморијалним именом у генитиву (типа: Улица краља Милутина), реч улица је најчешће испустива па се у складу с општим правилом тада прва реч властитог имена у новом облику пише великим почетним словом: Станујем у Краља Милутина, а она у Владике Данила.

Напомена 2: Реч улица пише се малим почетним словом кад је придодата имену, а сувишна је и нема је у регуларном (језички коректном) називу (уп. нпр.: Пуста улица Илица у Загребу [...]) и када је употребљена у облику множине (нпр.: У улицама Марка Краљевића, Цара Лазара и у Косовској неће бити струје...). Међутим, реч улица је неизоставна у именима као Улица платана, Улица бродараца [...] и увек се, наравно, пише великим словом" (Правопис 2010: 63, подвлачење је наше, В. И.).
}

2.5. Чини се да увођење категорије испустиви - неиспустиви део имена, када се он односи на реч улииа у званичном називу, уместо да прецизира правописну регулативу на овом пољу микротопонимије и пресудно утиче на употребу малог или великог слова, само је додатно релативизује. Отуда су сви корисници Правописа, потпуно оправдано, у недоумици да ли је наведени члан факултативан или обавезан конституент званичног назива, што генерише дилеме и грешке у писању, а то даље доводи до потпуног заобилажења овог дела градива на контролним задацима, испитима и другим правописним проверама од основношколског до универзитетског нивоа.

в) Правопис српског језика М. Дешића (школско издање)

2.6. Као школско издање, овај правопис, који је усклађен са Матичиним Правописом, писан је тако да се уз репрезентативне примере нуде јасна објашњења. Иако ни у овом приручнику није донесена коначна и једноставна одлука о писању назива улица, аутор је, чини се, на корак од таквог решења. Његова објашњења могу се подвести под три случаја: 
(1) Називи улица пишу се великим почетним словом прве речи - без обзира на место речи улица у називу (Улица српских владара, Улица цุарище Милице, Улица липа; Таковска улица; Српских владара, Таковска; Булевар мира, Трг Републике $)$;

(2) Реч улиия на почетку пише се малим словом када је у множини и праћена посебним називима (улице Омладинских бригада и Таковска);

(3) Реч улииа на почетку пише се малим почетним словом испред назива чији није званични део (улица Ауто-пут, улица Теразије, улица Кружни пут, улица Зелени венач; улица Српских владара).

Једино се последњи случај може сматрати потенцијалним извором дилема, будући да се њиме уводи поменута категорија испустиви - неиспустиви део имена. Међутим, сви наведени примери из треће групе, осим последњег, евидентно не садрже реч улица; она је у њима само општа реч за којом тек следи званични назив - именица или именичка синтагма у номинативу - у коме се некада чак налази лексема која је неправи синоним именици улица (исп. пут, венаи), што додатно поткрепљује полазно тврђење.

2.7. Последњи наведени пример - улица Српских владара, одн. Улица срnских владара (у првој групи) - и опаска која га прати: „кад се напише Улица српских владара, прва реч је почетак имена" (Дешић 2015: 77), односно - кад се напише улица Српских владара, прва реч је необавезна, општа, па самим тим испустива, имплицитно саопштава да правописци не могу лако пресећи са одлуком јер правопис најчешће зависи од ванјезичких чињеница, а званичним називима улица не може се лако ући у траг. Будући да за оба од два могућа решења имамо правописно прихватљиво објашњење, на нама је да такву ситуацију олакшамо тако што ћемо се определити за једно тумачење и њему остати доследни.

\section{3. Писање назива улица у наставним програмима за основну и средњу школу}

3.1. Према званичном наставном програму ученици се сусрећу са правилима о писању великог слова већ у првом разреду основне школе, а у другом разреду усвајају основна правила за писање имена улица: „Употреба великог слова у писању личних имена и презимена, надимака уз лично име, имена животиња, вишечланих географских имена и улица (једноставнија решења). Писање адресе" (Наставни програм за први и други разред основног образовања и васпитања; подвлачење је наше, В. И.). У трећем разреду они проширују правописна знања, а са њима и „писање назива улица”, како је наведено у Наставном програму за овај разред. У последњем - четвртом - разреду првог циклуса основног образовања у одељку програма о правопису нема речи о писању адреса, већ се знања проширују осталим правописним правилима.

\footnotetext{
${ }^{6}$ За разлику од овог решења, видели смо да Правопис МС налаже писање Трг републике.
} 
3.2. Увидом у наставни програм за други циклус основног образовања можемо закључити да се правила о писању великог слова уче и(ли) увежбавају у свим разредима. Различити одељци који се тичу ове правописне области распоређени су тако да се обрађују у петом и шестом разреду, док су седми и осми разред предодређени за обнављање и утврђивање. Прецизније говорећи, обрада ових правила изгледа овако: пети разред - (1) присвојни придеви на -ов/-ев, -ин, одн. -ски/-шки/-чки; (2) вишечлана географска имена; (3) називи организација; (4) заменица $B u$; шести разред - (1) заменице $B u, B a w$; (2) имена васионских тела; седми разред - Ø; осми разред - Ø7. Дакле, наставни програм за старије разреде основне школе не издваја посебно писање назива улица и тргова, али наводи писање назива васионских тела и организација, па остаје помало нејасно због чега је баш ова (али и многе друге), по нашем мишљењу, за функционалну писменост важна правописна партија остала занемарена. Треба још приметити да се, према наставном програму, ученици у старијим разредима основне школе упућују на школско издање правописа и навикавају на његову употребу.

3.3. Ако погледамо распоред правописних области у наставном програму за гимназије, можемо видети да се сва правила писања великог слова уче и обнављају једино у првом разреду, а у наставном програму ниједно од њих није именовано посебно, будући да се усвајају у тоталитету. Сваки наредни разред предвиђен је за друге правописне области ${ }^{8}$, а ортографска правила увек прате и одговарајуће правописне вежбе. (Детаљније о овоме исп. Брборић 2015a; Брборић 2015б.)

\section{4. Писање назива улица и тргова у уџбеницима за основну и средњу школу}

4.1. За потребе овог рада прегледали смо уџбенике трију најзаступљенијих издавача који се користе у нашим школама: Klett-a, Завода за уџбенике и Новог Логоса. Занимало нас је у којим разредима је представљена ова правописна област и у којој мери. Односно, хтели смо се уверити у компатибилност уџбеничке грађе са актуелним наставним програмом. Постојање / непостојање писања назива улица и тргова у школским граматикама поменутих издавача представићемо табеларно 9

\footnotetext{
${ }^{7}$ Ознака Ø говори да у наведеним разредима нема обраде нових правила о великом слову, већ се у њима проверава, понавља, увежбава и систематизује оно што је дотада научено.

${ }^{8}$ Тако се у другом разреду гимназије учи: „Састављено и растављено писање речи. Правописни знаци. Скраћенице. Растављање речи на крају ретка”, у трећем: „Транскрипција речи из страних језика (основни принципи и примери)", а програм правописа за четврти разред представљен је једном речју - „Интерпункција” (Наставни програм за гимназије).

9 Због ограниченог простора, овде нећемо детаљно анализирати приступ овој правописној области у сваком уџбенику понаособ. Таквој анализи треба посветити цео један рад.
} 
а) Основна школа

\begin{tabular}{|l|c|c|c|c|}
\hline Издавачи & 5. разред & 6. разред & 7. разред & 8. разред \\
\hline Klett & - & $(+)$ & - & + \\
\hline $\begin{array}{l}\text { Завод за } \\
\text { уџбенике }\end{array}$ & - & - & - & + \\
\hline Нови Логос & - & $(+)$ & - & + \\
\hline
\end{tabular}

б) Средња школа

\begin{tabular}{|l|c|c|c|c|}
\hline Издавачи $^{10}$ & 1. разред & 2. разред & 3. разред & 4. разред \\
\hline Klett & + & - & - & - \\
\hline Нови Логос & + & - & $/ 11$ & $/$ \\
\hline
\end{tabular}

4.2. Увидом у школске граматике могли смо закључити да се у њима ученици у основној школи са писањем назива улица и тргова сусрећу у шестом разреду, али не системски, уз навођење правила, већ само кроз поједине задатке за понављање/вежбање раније усвојеног знања. Објашњења за писање адреса они добијају тек у осмом разреду: „Великим словом пише се само прва реч у називу, а остале малим, изузев ако нису властите: [...] имена делова града, имена тргова, улица [...] Трг ослобођења, Булевар краља Александра, Карађорђева улица...)" (Ломпар 2017: 87, [Klett]). Ова правила ученицима ће се презентовати у средњој школи, и то једино у првом разреду. Уџбеник Klett-a доноси готово идентично објашњење као и у основној школи: „Имена делова града, имена тргова, улица (ако су речи улица или трг на првом месту, пишу се великим словом): [...] Трг ослобођења, Студентски трг, Булевар краља Александра, Карађорђева улица, Кнез Михаилова улица ( = Улица кнеза Михаила), Љермонтовљева улица и сл.” (Ломпар 2012: 117). Нешто детаљнији је уџбеник Новог Логоса, који показује да се у писању назива улица треба водити критеријумом придодатог или неизоставног члана назива (Кецман и др. 2016: 247) ${ }^{12}$. Међутим, пракса показује да је тај критеријум врло дискутабилан јер почива на језичком осећању појединца, па даје неуједначене резултате. У овим средњошколским уџбеницима писање назива улица налази се и у неколико задатака за вежбање који долазе иза наве-

\footnotetext{
${ }^{10}$ Не узимамо у обзир Заводову граматику (Станојчића и Поповића) јер се у њој правописне области не обрађују.

${ }^{11}$ Уџбеници Н. Логоса за трећи и четврти разред средње школе још нису у употреби у школској пракси.

${ }^{12}$ У уџбенику Новог Логоса за осми разред наводе се исти критеријуми - неодвојивог или одвојивог члана назива, што директно утиче на писање речи улица великим, односно, у другом случају, малим словом.
} 
дених правила. На основу свега излази да уџбеници прате наставни програм и за основну и за средњу школу, али да немају истоветан приступ у презентовању правила, тј. критеријума за писање великог слова. Уз ово додајемо да бисмо можда ипак очекивали да је у основној школи ово правило објашњено већ у шестом разреду, а да је у осмом оно нешто обухватније илустровано. Прецизнија објашњења, чини се, потребна су и средњошколским граматикама.

\section{5. Задаци са такмичења у основној и средњој школи}

5.1. Недовољно искристалисана објашњења у нашим правописима и уџбеницима одражавају се и на заступљеност ове области (тачке правописа) у задацима на такмичењима из српског језика и језичке културе. За потребе ове анализе прегледали смо задатке са свих нивоа такмичења од школске 1999/2000. године до 2015/16. (за основну школу), односно до 2014/15. (за средњу школу). Овај временски распон обухвата 170 тестова за основну и 192 теста за средњу школу - дакле, укупно 362 теста, односно 7240 такмичарских задатака.

Ситуација у њима је оваква:

\begin{tabular}{|c|c|}
\hline $\begin{array}{c}\text { а) Задаци са такмичења у основној } \\
\text { школи }(1999 / 2000-2015 / 16)\end{array}$ & $\begin{array}{c}\text { б) Задаци са такмичења у средњој } \\
\text { школи }(1999 / 2000-2014 / 15)\end{array}$ \\
\hline $\begin{array}{l}\text { V разред - } \\
\text { VI разред - } 2 \text { задатка } \\
\text { VII разред - } \\
\text { VIII разред - }\end{array}$ & $\begin{array}{l}\text { I разред - } 1 \text { задатак } \\
\text { II разред - ø } \\
\text { III разред -2 задатка } \\
\text { IV разред - ø }\end{array}$ \\
\hline 2 & 3 \\
\hline
\end{tabular}

a) На такмичењима за основне школе задаци који проверавају познавање писања улица и тргова јавили су се свега два пута, и то у шестом разреду. Један је био затвореног типа (вишеструки избор) (1), други - отвореног (са захтевом да се дата реченица, у којој је проверавано неколико правописних правила, препише исправно) (2). Овде преносимо форму задатака у целини.

1)

Заокружи слово испред правилно написане реченице:

a) Марко живи у таковској улици.

б) Марко живи у Таковској Улици.

в) Марко живи у Таковској улици. 
2)

Следећа реченица је у управном говору. Препиши је исправно писаним словима и додај све знаке интерпункције:

ДОЋИЋЕШ КОД МЕНЕ ДА УЧИМО БИЈОЛОГИЈУ РЕЧЕ МИША А ЈА СТАНУЈЕМ У БУЛЕВАРУ ВОЈВОДЕ МИШИЋА ЈЕДНОЈ ОД НАЈ ДУЖИХ БЕОГРАДСКИХ УЛИЦА.

Можемо приметити да ни у једном од ова два задатка нема примера у коме је у називу улице лексема улий на првом месту (Таковска улица, Булевар војводе Мишића). Отуда, ови примери спадају у оне који су јасни, школски, недвосмислени и не изазивају колебања.

б) На средњошколском нивоу у само три задатка која испитују познавање писања великог слова проверавано је и писање назива улица и тргова. У њима се ученици опредељују за правилно написане називе (задатак за први разред, (3)) или пак исправљају облике које сматрају неправилним (задаци за трећи разред $(4,5))$.

3)

Подвуци правилно написана властита имена:

Студентски Трг, Музеј Другог српског устанка, Историјски Музеј Србије, Храм Светога Саве, Пећка Патријаршија, Радио-телевизија Београд, Улица Кнеза Михаила.

4)

У следећој реченици исправи погрешно написана мала слова:

мој друг рале иде у тринаесту београдску гимназију, која се налази на бановом брду, у љешкој улици.

\section{5)}

У следећој реченици исправи мало слово у велико тамо где је потребно:

Мој друг живи у улици платана, а студира на филолошком факултету универзитета у београду, који се налази на студентском тргу, близу трга републике.

У сваком од ова три средњошколска задатка нашао се по један назив улице. Два задатка $(3,5)$ садрже примере у којима је лексема улииа на првом месту у називу (Улииа кнеза Михаила, Улииа платана), док се у једном (4) она налази на другом месту (Љешка улииа). Међу овим примерима ученицима су једино прва два наведена могла стварати дилеме како написати реч улица, будући да се она у њима јавља на почетку. У истим задацима $(3,5)$ тестира се и познавање писања назива тргова (Студентски трг, Трг Републике). 
5.2. На основу увида у такмичарске задатке за основну и средњу школу можемо закључити да се у њима питања која се тичу познавања имена улица и тргова врло ретко срећу. У распону од петнаестак школских година пронашли смо само 5 таквих задатака. Процентуално говорећи, овим питањима припада само $0,07 \%$, што је мање и од једног промила. ${ }^{13}$ Таква ситуација је у некој врсти раскорака са потребама функционалне писмености, будући да се са писањем адреса веома често сусрећемо у свакодневној комуникацији. Занимало нас је какав однос наставници српског језика данас имају према овој теми, па смо у ту сврху спровели једну анкету. Наредна тачка доноси њен опис.

\section{6. Анкетно истраживање}

6.1. На Републичком зимском семинару за наставнике и професоре српског језика и књижевности у фебруару 2018. године анкетирали смо 100 наставника основних и средњих школа из Србије ${ }^{14}$ непосредно пре радионице на којој смо се бавили проблемима писања назива улица и тргова у наставној пракси и предлозима за њихово превазилажење. Занимало нас је шта наставници мисле о овој тачки правописа - колико је она јасно представљена у уџбеницима и приручницима које користе, колико су они сами сигурни у правила писања назива улица, а колико њихови ученици, па и остале колеге запослене у настави. Такође, хтели смо проверити да ли је ово област која се често јавља на њиховим проверама писања великог слова или се, пак, она избегава. На самом крају, затражили смо од наставника да се определе за тачно написане називе улица. Анкета је имала осам питања, на која је одговор требало дати заокруживањем, па је испитаницима требало тек неколико минута да је попуне. Овде ћемо укратко представити њене резултате.

6.2. Разлог за одабир ове теме оправдан је одговорима већ на прво питање у анкети. Наиме, на дату тврдњу У уцбенищима и приручнищима (које користите у настави) писање назива улица и тргова приказано је сасвим јасно и не ствара недоумице чак је 79\% наставника одговорило заокружујући одговор не. То је потврдило нашу претпоставку да и наставници имају честе дилеме када је посреди писање адреса, што се директно одражава на наставу правописа у овом сегменту.

6.3. Са друге стране, у правописним проверама наставници не заобилазе област писања назива улица и тргова, али можемо закључити да на њој не инсистирају сви. Само 12\% наставника рекло је да ретко проверава ову област, 42\% наставника понекад, а 46\% наставника определило се за одговор често. У раз-

\footnotetext{
${ }^{13}$ Број задатака који испитују познавање писања имена улица и тргова није нарочито већи ни у тестовима за Завршни испит у основном образовању и васпитању.

${ }^{14}$ Анкету је радило 75 наставника запослених у основној школи и 27 средњошколских наставника (запослених у гимназијама, односно у средњим стручним школама); 3 наставника запослено је у по две школе истовремено: основна школа и гимназија; основна школа и средња стручна школа; гимназија и средња стручна школа.
} 
говору са некима од њих сазнали смо да на тим проверама дају примере који су јасни и не узрокују могућа двострука решења; реч је о улицама које на почетку назива немају лексему улица. ${ }^{15}$

6.4. Већина наставника има дилеме у вези са писањем назива улица и тргова, иако за припрему, обраду и(ли) утврђивање наставних јединица из правописа не користе само основну уџбеничку литературу, већ и друге приручнике. На питање којом се литературом том приликом служе, наставници су одговорили овако: граматику користи 63\% наставника, радну свеску 46\%, Правопис српскога језика Матице српске $80 \%{ }^{16}$, док Правопис сриског језика М. Дешића (приручник за школе) у настави употребљава тек $21 \%$ наставника. ${ }^{17}$ Анкета показује да се у настави правописа најчешће користи Матичин Правопис, док се уџбеничка литература, парадоксално, на овом пољу мање употребљава - граматику и радну свеску користи око половина испитаника, док се за употребу школског правописа опредељује још мањи број наставника.

6.5. Три питања у анкети односила су се на процену познавања писања назива улица и тргова и то - 1) ученика, 2) наставника српског језика и 3) наставника других предмета. Наставници су свој став о свакој групи изражавали ординалном вредности на Ликертовој скали, од 1 до 5, идући од најнижег степена знања (1) до највишег (5).

6.5.1. Резултати показују да се знање наших ученика о овим правописним правилима претежно може оценити оценом 3 (61\%); оцену 2 дало је 23\% наставника, а оцену 4-14\%; само 2\% наставника мисли да ученици одлично познају правила о писању назива улица и тргова.

6.5.2. Наставници српског језика сопствено познавање писања назива адреса углавном (61\%) оцењују оценом 4. Незанемарљив број наставника, једна четвртина, сматра да је њихово знање на просечном нивоу, оценивши знање србиста оценом 3. Врло ретко, тек $1 \%$, наставничко знање оцењује оценом 1 , нешто више њих (4\%) оценом 2, а има наставника (9\%) који сматрају да је знање њихових колега на завидном нивоу, па су се определили за оцену 5. Интересантно је да исти проценат наставника (61\%) себи даје оцену 4, а ученицима оцену 3.

\footnotetext{
${ }^{15}$ Нпр. Балканска улица, Призренска улица, Немањина, Булевар ослобођења, Булевар краља Александра. Уз то, неки наставници често правила поједноставе и тако их и проверавају; међутим, она као таква не обухватају све случајеве, па се ученици поново могу наћи у недоумици када треба да напишу неки конкретан назив.

${ }^{16}$ Уз назив овог правописа, наставницима је била понуђена линија да њој допишу годину издања Правописа Матице српске који користе. Највећи број њих (око 50\%) навео је 2010. годину, а спорадично су се јављале и године каснијих, прештампаваних издања. Интересантно је да има наставника који су навели и 1993. годину, а један наставник користи још увек издање Правописа из 1960. Од свих наставника који су ову опцију заокружили, трећина није навела ниједну годину.

${ }^{17}$ Поред ових одговора, који су били понуђени, наставници су имали простора да наведу и наставно средство које користе, а није ниједно од понуђених. Тако су се на том месту нашли одговори: [користим] Наставни материјал (вежбања); друге правописе; Речник Матице српске; наставне листове.
} 
6.5.3. Најзад, колико наставници других предмета познају ову правописну подобласт делимично указује на степен функционалне писмености образованих појединаца запослених у просвети. Њихове колеге србисти су знању нефилолога (као и наставника страних филологија), на основу општег утиска, претежно доделили оцену 2 (чак 40\% испитаника). Нешто мањи проценат (33\%) дао је оцену 3 , док чак $22 \%$ наставника сматра да се наставници других предмета веома лоше сналазе са правилним писањем назива улица, заокруживши на скали вредност 1. Ниједан испитаник се није определио за оцену 5.

6.6. У последњем питању у анкети наставници су имали да заокруже правилно написане називе улица и тргова. Било је понуђено осам реченица. Исти назив улице или трга јавио се у две реченице, написан на два начина: (а) Живим у улищи Балканској. (б) Живим у Улищи балканској. (в) Срели смо се у Улищи српских владара. (г) Срели смо се у улици Српских владара. (д) Наћи ћемо се на Тргу републике. (ђ) Наћи ћемо се на Тргу Републике. (е) Дођи у улииу Кнеза Милоша. (ж) Дођи у Улииу кнеза Милоша. Примери назива улица на почетку имају лексему улица, па нас је занимало како наставници решавају те случајеве - да ли наведену реч пишу великим почетним словом или пак сматрају да она није део званичног назива, па је пишу малим словом. Такође нас је интересовало да ли ће истоветно поступити са свим моделима назива, како на индивидуалном, тако и на колективном плану (улица + придевска одредба; улица + синтагма у генитиву; улица + меморијално име у генитиву), или ће, можда, структура назива утицати на избор великог слова. Поред тога, интересантно је било видети шта наставници мисле о писању Трга републике / Трга Републике, назива који наши правописи неусаглашено третирају. На самом крају, хтели смо утврдити како наставници тумаче текст правописа и у којој мери су свесни допуштених двојаких могућности у свим овим случајевима; такорећи, да ли има наставника који су заокружили све понуђене реченице као тачне, будући да се оне заиста могу уклопити у тумачења актуелних правописа - Матице српске и М. Дешића.

6.6.1. Анализа наставничких одговора на ово питање указала је на неколико важних закључака. Наиме, ако погледамо укупан резултат, видећемо да су се за неке одговоре наставници већином определили, док су неке друге ређе заокруживали. Највећи број наставника (89\%) означио је као исправан пример под в) - Срели смо се у Улици српских владара - а такође и њему аналоган, пример под ж) - Дођи у Улииу кнеза Милоша - за који се определио такође висок проценат (73\%) испитаника. Њихове „парњаке” наведене под г), односно е), у којима је улииа написана малим словом, наставници су ређе заокруживали (г) - $12 \%$, е) - 28\%). Са друге стране, реченице под а) Живим у улици Балканској и б) Живим y Улици балканској значајније су поделиле мишљења наставника. За први случај определило се $47 \%$, док $45 \%$ мисли да је исправан други начин писања. ${ }^{18}$ Иако је у свим овим примерима лексема улища на почетку назива, наставници немају према њима кохерентан однос. Када из ње следи синтагма, односно меморијал-

${ }^{18}$ Било је и оних који нису заокружили ни једну ни другу опцију. 
но име у генитиву, већина наставника сматра да је улица део званичног назива и да је треба писати великим словом. Међутим, када иза ње долази придевска одредба у номинативу, колебање је израженије. У случају писања назива (д) Трга републике, односно (ђ) Трга Републике, већина наставника определила се за пример под (д) (72\%), што је било и очекивано, јер је то решење које Правопис Матице српске сматра једино исправним, а тај правопис, како смо видели, користи највећи број наших наставника (80\%). Другачије правило у овом случају успоставља Правопис М. Дешића, а оно је било дато у примеру под (ђ). Међутим, само 29\% испитаника определило се за овај одговор, како смо и очекивали на основу процента наставника који користи овај правопис у настави (21\%).

6.6.2. Дакле, одговори на последње питање у анкети указују нам да, свеукупно гледано, наставници немају истоветан приступ називима улица, те да је њихово знање неуједначено. Када се ова лексема нађе на првом месту у називу они ће је углавном сматрати делом назива и писати великим словом, осим ако она није праћена неком придевском одредбом (уп. Улиц̧а балканска / улицуа Балканска) - у том случају мишљења наставника ће се готово равноправно поделити: једна половина се опредељује за један начин, а друга половина за други начин писања. Што се писања назива Трга републике / Трга Републике тиче, ни ту одговори нису сасвим усаглашени, мада се наставници много чешће опредељују за први начин писања, прописан Матичиним Правописом. Увид у индивидуалне одговоре такође нам је био значајан јер показује да ли се појединци колебају или су били доследни у одговорима, па они који сматрају да је улица део назива, они су се опредељивали само за називе са великим $\boldsymbol{\boldsymbol { Y }}$ на почетку (Улица балканска, Улиц̧а српских владара, Улица кнеза Милоша), а они који ову лексему сматрају само општом именицом иза које тек следи назив, они су доследно заокруживали њихове дате „парњаке” (улица Балканска, улица Српских владара, улица Кнеза Милоша). Анализа анкетних листића показала је да таквих појединаца има тек нешто више од половине ${ }^{19}-57 \%$, док је преосталих $43 \%$ испитаника недвосмислено изразило колебање заокружујући мешовите одговоре (нпр. улица Балканска, Улица српских владара, улица Кнеза Милоша и сл.). На крају треба рећи да су на само једном анкетном листићу (1\%) били заокружени сви примери, уз коментар да су према нашим правописима сва решења прихватљива.

6.7. На основу анализе спроведене анкете излази да су дилеме у писању назива улица изражене и на макро и на микро плану. Друкчије речено, не само да колебање постоји на нивоу колектива, у коме се један његов део опредељује за један начин писања, а други део за други начин него готово половина појединаца у том колективу има различита решења за тип назива у коме је лексема улица на почетку.

\footnotetext{
${ }^{19}$ У наведени квантум (57\%) улази и један број наставника који се нису определили ни за једну од понуђених опција - улица Балканска или Улица балканска. Објективно, и они се колебају, само то нису изразили заокруживањем различитих опција, већ одсуством одговора. Отуда овај проценат суштински једва прелази $50 \%$.
} 
На самом крају намеће се есенцијално питање: Како олакшати закомпликовану правописну ситуацију, а остати доследан важећем Правопису? Овде ћемо, као својеврстан закључак, понудити могуће разрешење.

\section{7. Пет правила за писање назива улица и тргова}

7.1. Узимајући у обзир структуру назива улица у српском језику, можемо, пре свега, издвојити два основна типа. Први тип чине називи који садрже лексему улица (I), а други који је не садрже (II). У оквиру првог типа издваја се неколико подтипова. Када је присутна у називу - улица може заузимати различиту позицију: на почетку (иницијалну) (Іа тип) или на крају (финалну) (Іб тип). Притом, она некада може бити само изостављена (Ів тип).

7.2. Типови Іб, Ів и II не задају у писању никакве тешкоће, будући да ту треба само применити правило о великом почетном слову прве речи у називу: Балканска улииа, Немањина, Кружни пут. Пажљивим тумачењем текста наше ортографске норме неизоставно се, како смо видели, намећу дилеме у вези са писањем назива типа Іа. Њих узрокује напомена у Правопису МС у којој се истиче да се реч улица пише малим словом ако је придодата имену, тј. ако је нема у регуларном називу. На том месту се природно (и врло често) намећу питања: како ћемо знати када је реч улица део званичног назива, а када није? Како се правописно понашати у сваком конкретном случају?

7.3. Ова тачка наших правописа (Матице српске и М. Дешића) чини се недовољно прецизном, па ћемо се сада потрудити да ова правила прецизирамо, сврставајући све називе у неколико група и наводећи правила која у њима треба применити:

1) Називи тргова и булевара: Студентски трг, Трг револуције, Булевар цара Лазара (немају реч улица) или називи улица са „природним” редоследом речи (атрибут + улица): Балканска улица, Прешевска улица (реч улица у финалној позицији) - велико почетно слово.

2) Називи у којима је лексема улица изостављена (не постоји у тексту): Кнез Михаилова, Немағина (придевски модел); Кнеза Милоша, Браће Рибникар, Интернационалних бригада (генитивни модел) - велико почетно слово.

3) Називи са речју улица на првом месту: Улица босанска (улица + придев у номинативу), Улииа кнеза Милоша, Улища српских владара, Улица платана (улища + именичка јединица (меморијално име, именичка синтагма, именица) у генитиву) - велико почетно слово. ${ }^{20}$

4) Када је у формуларима и готовим обрасцима написано скраћено ул., назив улице који следи пишемо великим почетним словом: ул. Мајке

${ }^{20}$ Одавде директно следи да се именица улииа праћена именичком јединицом у номинативу пише малим словом: улица Велике степенице, улица Миријевски венац, улица Кружни пут. 
Јевросиме, ул. Српских владара, ул. Балканска; ул. Чика Љубина, Небојшина и Васина.

5) Именица улица у множини или у једнини испред више назива пише се малим словом: затворене су улице Максима Горког, Немањина и Булевар ослобођења; у улици Војислава Илића, Интернационалних бригада и Милешевској - а назив који следи пишемо великим почетним словом.

Друкчије речено, када је реч улиц̧а на почетку назива, пишемо је великим словом ако:

1) иза ње следи придев у номинативу;

2) иза ње следи именичка јединица (меморијално име; именица, именичка синтагма) у генитиву.

У осталим случајевима, чак и ако је на почетку, пишемо је малим словом:

1) када је праћена нечим другим осим изнад наведеног (најчешће именичком синтагмом у номинативу);

2) када је у формулару написана скраћено;

3) када је дата у множини.

7.4. Закључна напомена. Наведена правила углавном представљају систематизовану форму објашњења датих у нашим актуелним правописним приручницима. Случај под 3) тиче се структуре назива који је извор читаве проблематике. Наша је препорука да се у њој примењује наведено правило, јер је утемељено у тексту правописа̂ и са осталим правилима даје систем од пет правила који покривају све могуће случајеве без остатка. Ако бисмо се њима водили, избегли бисмо бројне недоумице, писање адреса нам не би представљало проблем, а задаци на тестовима којима се проверава употреба великог слова, у складу са задацима функционалне наставе, чешће би проверавали писање ових вишечланих микротопонимијских назива.

\section{8. Неколико примера за вежбу са решењима}

1) СТАНУЈЕМ У УЛИЦИ КНЕЗА МИЛОША, БРОЈ 15.

2) ОНИ ЖИВЕ У УЛИЦИ 7. ЈУЛА.

3) СТАНОВАЛИ СУ У БОЖИДАРА АЏИЈЕ, А ЗАТИМ СЕ ПРЕСЕЛИЛИ У УЛИЦУ КОЈА СЕ ЗОВЕ СВЕТОГОРСКА.

4) ИСТУ УЛИЦУ У БЕОГРАДУ НЕКИ ЗОВУ УЛИЦОМ КРАљА МИЛАНА, А НЕКИ УЛИЦОМ СРПСКИХ ВЛАДАРА.

5) У УЛИЦИ ЗЕЛЕНИ ВЕНАЦ МОЖЕТЕ ПРОНАЋИ НЕКОЛИКО ЛЕПИХ РЕСТОРАНА.

6) ДО ТРГА РЕПУБЛИКЕ МОЖЕТЕ СТИЋИ ФРАНЦУСКОМ УЛИЦОМ, МАКЕДОНСКОМ, КОЛАРЧЕВОМ ИЛИ УЛИЦОМ ВАСЕ ЧАРАПИЋА. 
7) ЈЕСТЕ ЛИ ПРОБАЛИ КРОФНЕ У УЛИЦИ ИНТЕРНАЦИОНАЛНИХ БРИГАДА?

8) ЈУЧЕ СМО СЕ СРЕЛИ У НЕМАЬИНОЈ УЛИЦИ, НЕДАЛЕКО ОД ПОЗНАТОГ ТРГА СЛАВИЈА.

9) У УЛИЦИ БАЛКАНСКОЈ И ДАНАС ИМА НЕКОЛИКО ОБУЋАРСКИХ РАДЬИ.

10) МОЈА ОМИЉЕНА УЛИЦА ЈЕ КРУНСКА.

11) ПОСТОЈИ ЛИ ЈОШ УВЕК УЛИЦА ВЕЛИКЕ СТЕПЕНИЦЕ?

\section{Решења:}

1. Станујем у Улици кнеза Милоша, бр. 15.

2. Они живе у Улици 7. јула.

3. Становали су у Божидара Аџије, а затим се преселили у улицу која се зове Светогорска.

4. Исту улицу у Београду неки зову Улицом краља Милана, а неки Улицом српских владара.

5. У улици Зелени венац можете пронаћи неколико лепих ресторана.

6. До Трга републике (Републике) можете стићи Француском улицом, Македонском, Коларчевом или Улицом Васе Чарапића.

7. Јесте ли пробали крофне у Улици интернационалних бригада?

8. Јуче смо се срели у Немањиној улици, недалеко од познатог трга Славија.

9. У Улици балканској и данас има неколико обућарских радњи.

10. Моја омиљена улица је Крунска.

11. Постоји ли још увек улица Велике степенице?

\section{ЛИТЕРАТУРА И ИЗВОРИ}

Брборић 2015а: В. Брборић, „Неке дилеме око писања великог и малог слова", Научни састанак слависта у Вукове дане, Београд: Међународни славистички центар, стр. 91-101.

Брборић 2015б: В. Брборић, Правопис и школа, Београд: Друштво за српски језик и књижевност Србије.

Вељковић Станковић и др. 2015: Д. Вељковић Станковић и др., Тестови из српског језика: са општинског, окружног и републичког такмичењ аченика основних школа из српског језика и језичке културе, Београд: Друштво за српски језик и књижевност Србије.

Вељковић Станковић и др. 2016: Д. Вељковић Станковић и др., Тестови из српског језика: са општинског, окружног и републичког такмичењ ауеника 
основних школа из српског језика и језичке културе, Београд: Друштво за српски језик и књижевност Србије.

Вуловић 2016: Н. Вуловић, Српски језик и језичка култура: за шести разред основне школе, Београд: Завод за уџбенике.

Дешић 2015: М. Дешић, Правопис српског језика (иколско издање), Београд: Klett.

Драгићевић 2011: Р. Драгићевић, Српски језик и језичка култура: за 5. разред основне школе, Београд: Завод за уџбенике.

Кецман и др. 2016: В. Кецман, Граматика српског језика: за први разред гимназија и средюих стручних школа, Београд: Нови Логос.

Кликовац 2011: Д. Кликовац, Српски језик и језичка култура: за 8. разред основне школе, Београд: Завод за уџбенике.

Ломпар и др. 2016а: В. Ломпар и др., Граматика: српски језик и књижевност за трећи разред гимназија и средюих стручних школа, Београд: Klett.

Ломпар и др. 2016б: В. Ломпар и др., Граматика: српски језик и киижевност за четврти разред гимназија и средюих стручних школа, Београд: Klett.

Ломпар, Кликовац 2013: В. Ломпар, Д. Кликовац, Тестови из српског језика: са општинског, окружног/градског и републичког такмичења ученика средњих школа из српског језика и језичке културе, Београд: Друштво за српски језик и књижевност Србије.

Ломпар, Кликовац 2015: В. Ломпар, Д. Кликовац, Тестови из српског језика: са општинског, окружног/градског и републичког такмичења ученика средњих икола из српског језика и језичке културе, Београд: Друштво за српски језик и књижевност Србије.

Ломпар 2015: В. Ломпар, Граматика 5: српски језик за пети разред основне иколе, Београд: Klett.

Ломпар 2010: В. Ломпар, Граматика 6: српски језик за шести разред основне школе, Београд: Klett.

Ломпар 2013: В. Ломпар, Граматика 7: српски језик за седми разред основне школе, Београд: Klett.

Ломпар 2017: В. Ломпар, Граматика 8: српски језик за осми разред основне школе, Београд: Klett.

Ломпар 2012: В. Ломпар, Граматика: српски језик и књижевност: за први разред гимназија и средњих стручних икола, Београд: Klett.

Ломпар, Антић 2016: В. Ломпар, А. Антић, Граматика: српски језик и књижевност за други разред гимназија и средюих стручних школа, Београд: Klett.

Милановић 2009: А. Милановић, Српски језик и језичка култура: за 7. разред основне школе, Београд: Завод за уџбенике.

Наставни програм за гимназије: Српски језик и књижевност.

Наставни програми основног образовања и васпитања (од првог до осмог разреда). 
Пешикан 1996: М. Пешикан, „Правописна норма” у: Српски језик на крају века (ред. М. Радовановић), Београд: Институт за српски језик САНУ, стр. 171-179.

ПМС 1993: Правопис српскога језика, Нови Сад: Матица српска.

ПМС' 2006: Правопис српскога језика (иколско издање), Нови Сад: Матица српска.

ПМС 2010: Правопис српскога језика, Нови Сад: Матица српска.

Резултати анкете спроведене на 59. Републичком зимском семинару за наставнике и професоре српског језика и књижевности 9. фебруара 2018. године на Филолошком факултету Универзитета Београду.

Савовић и др. 2016: С. Савовић и др., Граматика српског језика за други разред гимназија и средњих стручних школа, Београд: Нови Логос.

Савовић и др. 2017: С. Савовић и др., Граматика за седми разред основне школе, Београд: Нови Логос.

Савовић 2011: С. Савовић и др., Граматика за шести разред основне школе, Београд: Нови Логос.

Срдић 2017: J. Срдић, Граматика за пети разред основне школе, Београд: Нови Логос.

Тестови 2008: Српски језик кроз тестове (прир. Босиљка Милић), Београд: Друштво за српски језик и књижевност Србије.

Ћећез-Иљукић и др. 2012: Д. Ћећез-Иљукић, Граматика за осми разред основне школе, Београд: Нови Логос.

Valentina M. Ilić

\author{
WRITING STREET AND SQUARE NAMES IN ORTHOGRAPHY AND SERBIAN \\ LANGUAGE TEACHING
}

Summary

This work analyzes the rules of writing street and square names in the Orthography of the Serbian Language by Matica srpska (1993), in the current Matica srpska's Orthography (2010), as well as in the Orthography of Serbian language by M. Dešić (school edition). Along with that, primary and secondary school curricula are being explored, as well as the presentation of this orthography point in the Serbian language textbooks of the three most widely used publishers in our schools. Examples that check writing street and square names at Serbian language competitions are represented and analyzed. The results of the survey conducted among 
teachers and professors of the Serbian language which examines their attitude towards this orthography topic are given. In the end, through five systematized rules, we offer solutions to overcome the current problem with writing street and square names.

Key words: orthography, street and square names, capital letter, curricula, textbooks, survey. 